\title{
プロピオン酸代替物質を用いた高延性バルクナノ結晶 $\mathrm{Ni}-\mathrm{W}$ 合金電析浴の開発
}

\author{
松井 功* 尾村直紀李明軍村上雄一朗多田周二
}

国立研究開発法人産業技術総合研究所構造材料研究部門

J. Japan Inst. Met. Mater. Vol. 80, No. 3 (2016), pp. 217-223

(C) 2016 The Japan Institute of Metals and Materials

\section{Development of Electrodeposition Bath Using a Substitute of Propionic Acid for Bulk Nanocrystalline Ni-W Alloys with High Ductility}

Isao Matsui*, Naoki Omura, Mingjun Li, Yuichiro Murakami and Shuji Tada

Structural Materials Research Institute, National Institute of Advanced Industrial Science and Technology (AIST), Nagoya 463-8560

A substitute for propionic acid, which is a complexing agent in the $\mathrm{Ni}-\mathrm{W}$ electrodeposition process for producing bulk nanocrystalline alloys with high ductility, was explored. Bulk nanocrystalline $\mathrm{Ni}-\mathrm{W}$ alloys were electrodeposited using electrolyte that primarily consisted of nickel sulfamate and sodium tungstate with sodium propionate and/or sodium gluconate. Their W content, impurity contents, microstructure, and mechanical properties were investigated. The $\mathrm{Ni}-\mathrm{W}$ alloys electrodeposited from conventional bath exhibited tensile strength of $1.66 \mathrm{GPa}$ and elongation of $6.5 \%$. Substitution of propionic acid by sodium propionate enhanced tensile elongation up to $11.3 \%$ along with high strength of $1.65 \mathrm{GPa}$. Also, substitution by sodium gluconate enhanced tensile strength up to $1.80 \mathrm{GPa}$ with elongation of $5.2 \%$. The results of this study demonstrate that the propionic acid in the $\mathrm{Ni}-\mathrm{W}$ electrodeposition process can be replaced by sodium propionate without property degradation.

[doi:10.2320/jinstmet.J2015052]

(Received August 19, 2015; Accepted September 15, 2015; Published January 22, 2016)

Keywords: electrodeposition, nanocrystalline metals, nickel-tungsten alloys, tensile properties, complexing agent

\section{1. 緒言}

近年，極めて高い強度や硬度を有するナノ結晶材料(結晶 粒径 $100 \mathrm{~nm}$ 以下) 1,2$)$ の作製が盛んに行われている．特に， 電解析出法(電析)は, ナノ結晶メタルの作製3-7), および機 械的特性評価用のバルク試料の作製 ${ }^{8-11)}$ ，を行うために広く 利用されてきた。これまでの機械的特性に関する研究によ り, ナノオーダーに抢ける結晶粒微細化効果 ${ }^{12-15)}$ や固溶強 化 ${ }^{16,17)}$ について明らかにされてきた. 同時に, 電析バルクナ ノ結晶メタルに塑性変形能の付与を行うために, 電析浴組成 の検討や電析条件の最適化が行われてきた. その結果, 従来 の高い強度を有するとともに 10\%を超える引張伸びを示す 高強度・高延性バルクナノ結晶メタルの作製が達成されてい る18-21). 実際に, 著者の松井らにより開発された Ni-W 電 析浴 (SPG 浴) は, $90 \%$ 程度の高い電流効率を示すとともに 引張強さ $1.5 \mathrm{GPa}$, 引張伸び $13 \%$ を示すバルクナノ結晶 $\mathrm{Ni}-$ $\mathrm{W}$ 合金の作製を可能にしている20).

電析バルクナノ結晶メタルは, 現在, その優れた機械的特 性に起因して, 電鋳金型や MEMS などの微少部材への応用 が期待されている. 一方で，これまでに報告された多くの電 析浴に扣いて, 錯化剂としてホウ酸が添加されているが,

\footnotetext{
* Corresponding author, E-mail: i-matsui@aist.go.jp
}

1999 年にホウ素が, 水質污濁防止法の対象となり, その排 出值が, $10.0 \mathrm{mg} / \mathrm{L}$ 以下と定められた. また, ホウ素を含む 排水処理はコストが高く, 処理工程が複雑であるなどの問題 があり, ホウ酸を使用しない電析浴の研究・開発が行われて いる ${ }^{22-25)}$ 。このような背景から, 著者の松井らにより開発 された SPG 浴では錯化剂として, 渡辺ら 22 によって行われ た $\mathrm{Ni}$ 電析におけるホウ酸代替物質の検討を元に, プロピオ ン酸とグルコン酸ナトリウムを用いてきた ${ }^{20)}$.しかしなが ら, プロピオン酸は, 悪臭防止法の規制対象試薬である. そ れゆえ, ハンドリングやコスト面で実際の工場に扮ける操業 が, 困難であると考えられる. そこで, 本研究では, 電析バ ルクナノ結晶 $\mathrm{Ni}-\mathrm{W}$ 合金の工業的な応用展開に向けて, 高 強度・高延性を示すバルクナノ結晶 $\mathrm{Ni}-\mathrm{W}$ 合金の作製が可 能な規制対象試薬を用いない電析浴の開発を目的とした.

\section{2. 実 験 方 法}

本研究では, プロピオン酸の代替物質を探索するために 6 種類の $\mathrm{Ni}-\mathrm{W}$ 電析浴を準備した. 従来浴として, 光沢剂に サッカリンナトリウム, 錯化剤にプロピオン酸とグルコン酸 ナトリウムを用いた SPG 浴 ${ }^{20)}$ を準備した. また, 開発浴と してプロピオン酸をプロピオン酸ナトリウムに変更した SPNG 浴, および錯化材をグルコン酸ナトリウムのみにし た SG 浴を作製した. SG 浴については，グルコン酸ナトリ 
ウムの添加量を $6.4 〜 25.6 \mathrm{~g} / \mathrm{L}$ の範囲で変化させた 4 種類の 浴(SG6, SG13, SG19, SG26)を用いた. 各種電析浴の詳細な 浴組成を Table 1 に示す．各種電析浴と $1 \mathrm{~L}$ 電析浴槽を用い て 96 時間の電析を行い, $50 \mathrm{~mm} \times 30 \mathrm{~mm} \times 1.2 \mathrm{~mm}$ のバ ルクサンプルを作製した。ただ， SG6 浴においては電析 中に皮膜表面にガス発生に起因した電析不良が確認されたた め, 電析開始から 48 時間後に停止した。本研究では，陽極 としてニッケル板 $(99.98 \%)$ とタングステン棒 $(99.95 \%)$ を, 陰極として銅板 (タフピッチ銅)を用いた。また，タングステ ン棒はチタンバスケットに入れ使用した。すべての電析は, 電流密度 $25 \mathrm{~mA} / \mathrm{cm}^{2}$, 浴温度 $50.0 \pm 0.5^{\circ} \mathrm{C}, \mathrm{pH} 4.0 \pm 0.1$ の 条件下で行った. 電源には, 直流電源(松定プレシジョン製, P4L18-2) を使用した。浴温度は, 温調器 (CHINO 製, $\operatorname{DB} 630$ (Z 制御アルゴリズム型))を用いて厳密に制御した. さらに, pH は, pH コントローラー(東興化学研究所製, TDP-51)を用いて一定に保った。 また, $\mathrm{pH}$ の調整には, $1.0 \mathrm{~mol} / \mathrm{L}$ スルファミン酸と $5.0 \mathrm{~mol} / \mathrm{L}$ 水酸化ナトリウムを 使用した。

電析後に, 電流効率 $C E$ を, 電析前後における陰極の質量 差 $w$ 抢よび後述の電析試料における $\mathrm{W}$ 含有量 $x_{\mathrm{W}}$ から算出 した. 算出には以下の式 $(1)$ を用いた.

$$
C E=\frac{w n F}{I t} \mid\left(\left(1-x_{\mathrm{W}}\right) A_{\mathrm{Ni}}+x_{\mathrm{W}} A_{\mathrm{W}}\right)
$$

Table 1 Bath composition ( $\mathrm{g} / \mathrm{L}$ ) for bulk nanocrystalline $\mathrm{Ni}-$ $\mathrm{W}$ alloys.

\begin{tabular}{lrrrrrr}
\hline \multicolumn{1}{c}{ Chemicals } & SPG & SPNG & SG6 & SG13 & SG19 & SG26 \\
\hline Nickel sulfamate & 300.0 & 300.0 & 300.0 & 300.0 & 300.0 & 300.0 \\
Sodium tungstate & 9.7 & 9.7 & 9.7 & 9.7 & 9.7 & 9.7 \\
Nickel chloride & 5.0 & 5.0 & 5.0 & 5.0 & 5.0 & 5.0 \\
Propionic acid & 20.0 & - & - & - & - & - \\
Sodium propionate & - & 20.0 & - & - & - & - \\
Sodium gluconate & 6.4 & 6.4 & 6.4 & 12.8 & 19.2 & 25.6 \\
Saccharin sodium & 1.0 & 1.0 & 1.0 & 1.0 & 1.0 & 1.0 \\
Sodium lauryl sulfate & 0.3 & 0.3 & 0.3 & 0.3 & 0.3 & 0.3 \\
\hline
\end{tabular}

(a)

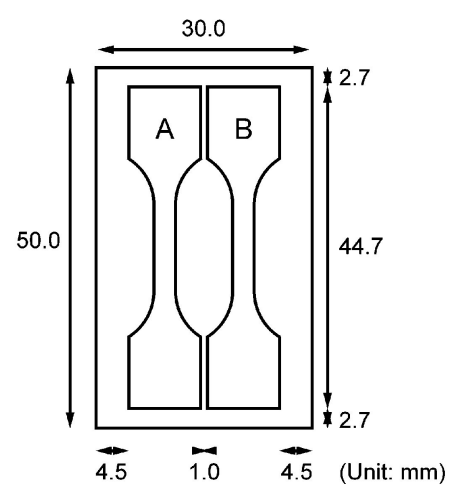

(c)

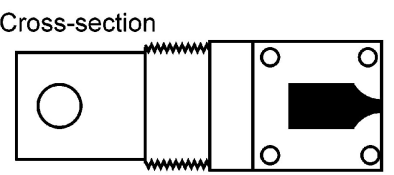

ここで, $n$ は価電子数であり, $F$ はファラデー定数であり, $I$ は電流值であり, $t$ は電析時間であり， $A_{\mathrm{Ni}}$ と $A_{\mathrm{W}}$ はそれぞ れニッケルとタングステンの原子量を示す. 電析サンプルの タングステン含有量をエネルギー分散型蛍光 $\mathrm{X}$ 線分析装置 (EDX，SHIMADZU 製，EDX-8000）にて測定した。ま た，炭素，硫黄含有量については，高周波燃焼赤外吸収法に て定量した. X 線回折装置 (XRD, Philp 製, X'Pert-MPD) を使用して， $\mathrm{Cu}-\mathrm{K} \alpha$ 線，管電圧 $30 \mathrm{kV}$ ，管電流 $40 \mathrm{~mA}$ の条 件下で, 結晶配向性を確認した.さらに, 得られた回折ピー クの半值幅とシェラーの式を用いて電析 $\mathrm{Ni}-\mathrm{W}$ 合金の粒径 を見積もった，算出した粒径が，妥当であるかを確認するた めに，透過型電子顕微鏡 (TEM，JEOL 製 JEM-2010)によ る微細組織の直接観察を行った. TEM 用観察試料は，イオ ンミリング加工により作製を行った．電析 $\mathrm{Ni}-\mathrm{W}$ 合金の機 械的特性評価として硬度試験と引張試験を実施した．硬度試 験として，ビッカース硬さをMATSUZAWA 製，MMT-X を用いて荷重 $500 \mathrm{~g}$ ，保持時間 $10 \mathrm{~s}$ にて測定した。測定点数 は, 12 点であり, 最大值と最小值を除いた 10 点の平均值を 算出した。引張試験は, SHIMADZU 製 AUTOGRAPH AG-X plusにより，ひずみ速度 $1 \times 10^{-3} \mathrm{~s}^{-1}$, 室温にて行っ た. 引張試験片は, バルクサンプルの中心部から, 放電加工 により 2 本切り出した (Fig. 1(a)). 試験片の形状および寸 法は，Fig. 1(b)に示すと抢りである。引張試験片に打ける 基板として用いた銅部分については，回転研磨機を使用し機 械的に取り除き，その後，平面研削盤により試験片厚さを $1 \mathrm{~mm}$ 程度に調節した。 また，装置付属の標準つかみ歯では 試験中にすべってしまい最終破断まで試験を行えなかったた め, Fig. 1(c)に示す専用治具につかみ部をはめ込久試験を 実施した。本治具を用いて得られる応力ーひずみ曲線を Fig. 1 (d) に示す。本治具を用いた場合, 引張試験片が治具に食 い込むまでに時間を要するため，試験開始後の応力の立ち上 がりがなだらかな領域が存在する。そこで， $0.2 \%$ 耐力 $\sigma_{0.2}$, 引張強度 $\sigma_{\mathrm{UTS}}$, 引張伸び $\varepsilon$ をそれぞれ Fig. $1(\mathrm{~d})$ に示

(b)
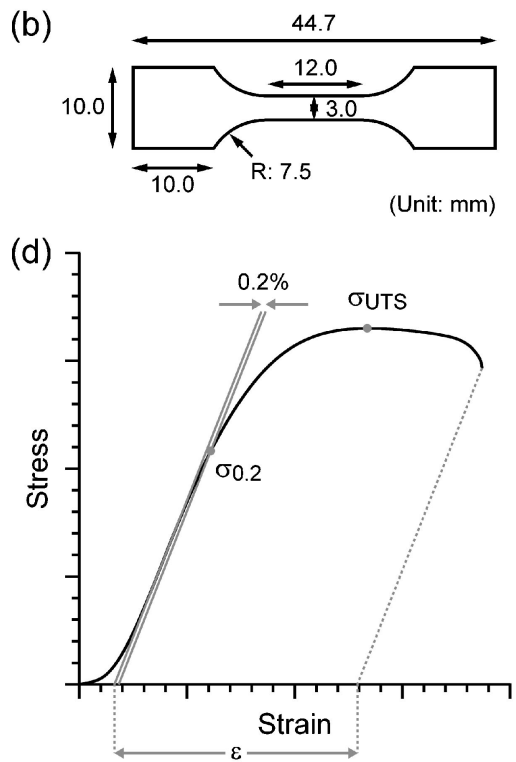

Fig. 1 (a) Image showing the position of tensile test specimens. (b) Shape of the tensile specimens. (c) Images of the tensile test tool. (d) Stress-strain curve obtained from a tensile test using the tensile test tool. 
すように決定した. 引張試験後, 試験片の破断面を走査型電 子顕微鏡 $(\mathrm{SEM}$, Hitachi 製 S-4800)にて観察した.

\section{3. 結果と考察}

6 種類の電析浴を用いて電析を行った. Fig. 2 に各種電析 浴から得られた試料の外観写真を示す。従来浴である SPG 浴から得られた電析 $\mathrm{Ni}-\mathrm{W}$ 合金の表面は, 光沢を有した平 滑なものであった．錯化剤をグルコン酸ナトリウムのみにし た SG6 浴から得られた電析 $\mathrm{Ni}-\mathrm{W}$ 合金の表面には, エッシ 部を中心にヤケが確認された. SG6 浴の電析時には, 基板 に多数の気泡が吸着していたことから, 高電流密度部である エッジ部に沶いて水素ガスが発生し, 析出を阻害したものと 考えられる. また, 電析時の水素ガス発生の要因として, グ ルコン酸ナトリウムの添加量 $6.4 \mathrm{~g} / \mathrm{L}$ がニッケルイオンおよ びタングステンイオンの錯体形成に対して不十分であると考 えられた。これに対して，グルコン酸ナトリウムの添加量を 増加した SG13 浴, SG19 浴, およびSG26 浴では, 電析部 の広域にわたって光沢を有した平滑な表面が確認できた．錯 化剂をグルコン酸ナトリウムとプロピオン酸ナトリウムにし た SPNG 浴から得られた電析 $\mathrm{Ni}-\mathrm{W}$ 合金においても，SPG 浴から得られた電析 $\mathrm{Ni}-\mathrm{W}$ 合金と同様に，電析部全域にお いて，光沢を有した平滑な表面が確認された。 また，エッジ 部について着目するとSPG 浴およびSPNG 浴から得られた 試料に抒いては絶縁部を巻き込むように被膜が成長してお り，その皮膜の成長は基板の裏面にまで達していた。一方で, SG 浴から得られた試料においては, SPG 浴やSPNG 浴の ような基板裏面への皮膜の侵入はなく，錯化剂の種類によっ て皮膜の成長形態が異なる結果となった.

各電析浴の電流効率を Table 2 に示す. 従来浴である SPG 浴の電流効率は， $88 \%$ であった. SPNG 浴は，SPG 浴 と同程度の 90\%を示した. 一方で, SG 浴では，93\%を超え る非常に高い電流効率が示された。しかしながら， SG6 浴 を用いた電析に抢いては, 電析中に水素ガス発生が起きるな ど析出反応以外の反応が起きていたと考えられた．これらの 副反応による生成物を被膜が巻き込むことによって，見かけ 上電流効率が高くなっている可能性がある. そこで, 各電析 試料のタングステン量に加えて, 電析プロセスに起因して電 析皮膜に混入する炭素, 硫黄の含有量について分析を行っ
た. 分析結果を Table 2 に示す. 電析中に水素ガスの発生が 起きた SG6 浴から得られた試料は炭素, 硫黄含有量がそれ ぞれ 0.93 at \% , 0.21 at\% と非常に高い值を示した. 一方で, 他の試料に扮いては, 炭素, 硫黄含有量がそれぞれ 0.05 at\%以下であった. 本分析結果より, SG13, SG19, SG26 浴の高電流効率は不純物の巻き込みによるものではないと考 えられた。

従来浴である SPG 浴から作製した試料のタングステン量 は, 1.2 at\%であり, SPNG 浴および SG13 浴から得られた 試料がそれぞれ 1.2 at\%と同様の值を示した。一方で, SG 浴から作製した試料のタングステン量は，グルコン酸ナトリ ウムの添加量の増加とともに減少していき(Fig. 3), SG26 浴から得た試料のタングステン量は 0.5 at \% と従来浴に比し て低い值を示した。また，グルコン酸ナトリウムの添加量が 同じである SPG，SPNG，およびSG6 浴を比較すると，プ

Table 2 Summary of current efficiency $(C E)$ of deposition bath and $\mathrm{W}, \mathrm{C}$, and $\mathrm{S}$ content of bulk nanocrystalline $\mathrm{Ni}-\mathrm{W}$ alloys.

\begin{tabular}{lcccc}
\hline Bath & $C E(\%)$ & $\mathrm{C}($ at $\%)$ & $\mathrm{S}($ at\% $)$ & $\mathrm{W}($ at\%) \\
\hline SPG & 88 & 0.05 & 0.05 & 1.2 \\
SPNG & 90 & 0.04 & 0.05 & 1.2 \\
SG6 & 93 & 0.93 & 0.21 & 3.1 \\
SG13 & 95 & 0.03 & 0.05 & 1.2 \\
SG19 & 96 & 0.03 & 0.05 & 0.8 \\
SG26 & 96 & 0.03 & 0.05 & 0.5 \\
\hline
\end{tabular}

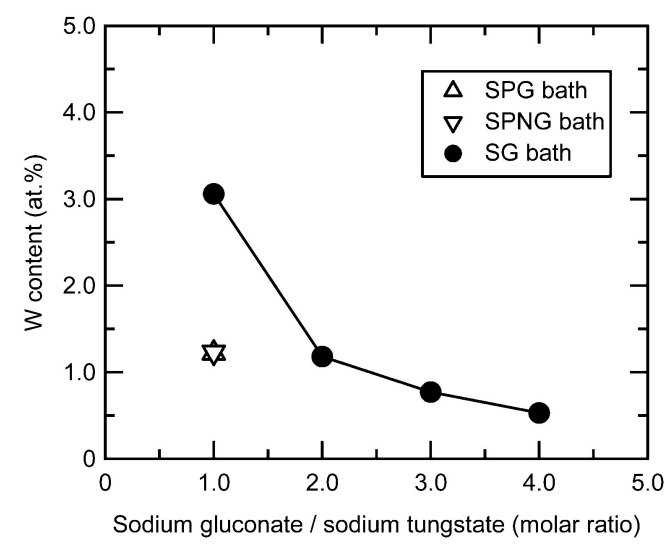

Fig. 3 Effect of sodium gluconate/sodium tungstate molar ratio on the $\mathrm{W}$ content of bulk nanocrystalline $\mathrm{Ni}-\mathrm{W}$ alloys.
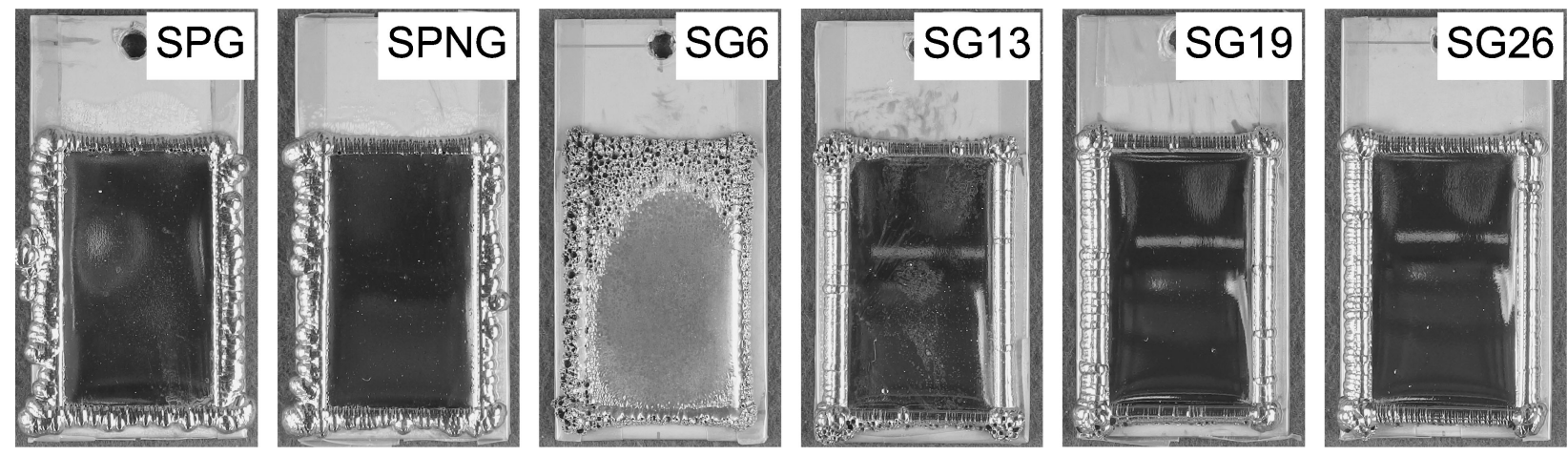

Fig. 2 Photographs showing the appearance of $\mathrm{Ni}-\mathrm{W}$ alloys electrodeposited by varying types of the complexing agents. 
ロピオン酸またはプロピオン酸ナトリウムを添加すること で, 電析試料のタングステン含有量が 3.1 at \%から 1.2 at $\%$ にまで減少した。これらの結果から, プロピオン酸, プロピ オン酸ナトリウム, 抢よびグルコン酸ナトリウムなどの添加 量により電析試料のタングステン含有量を制御することが可 能であることが示唆された.これらの錯化剂添加量とタング ステン含有量の詳細な関係については, 別報で報告する予定 である。

各種電析浴から得られた電析 $\mathrm{Ni}-\mathrm{W}$ 合金の $\mathrm{X}$ 線回折パ ターンを Fig. 4 に示す. 本研究で得られた試料からは, 二 ッケル由来の回折ピークのみが確認された。 また, 各 $\mathrm{Ni}-\mathrm{W}$ 合金における(111)，(200), および(220)面の配向度を

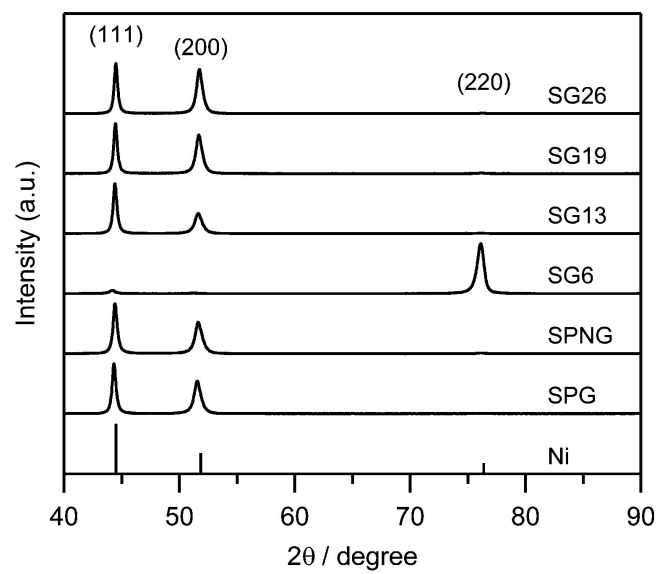

Fig. 4 XRD patterns of electrodeposited bulk nanocrystalline $\mathrm{Ni}-\mathrm{W}$ alloys.

Table 3 Measurement data for bulk nanocrystalline $\mathrm{Ni}-\mathrm{W}$ alloys.

\begin{tabular}{lccccc}
\hline \multicolumn{1}{c}{ Bath } & $d / \mathrm{nm}$ & $N_{111}$ & $N_{200}$ & $N_{220}$ & $H V / \mathrm{GPa}$ \\
\hline SPG & 25 & 0.98 & 1.54 & 0.04 & $4.88 \pm 0.02$ \\
SPNG & 24 & 0.99 & 1.48 & 0.09 & $4.95 \pm 0.04$ \\
SG6 & 11 & 0.09 & 0.03 & 7.26 & $5.21 \pm 0.15$ \\
SG13 & 24 & 1.14 & 1.14 & 0.06 & $4.98 \pm 0.05$ \\
SG19 & 26 & 0.91 & 1.69 & 0.05 & $4.78 \pm 0.04$ \\
SG26 & 27 & 0.85 & 1.83 & 0.03 & $4.71 \pm 0.03$ \\
\hline
\end{tabular}

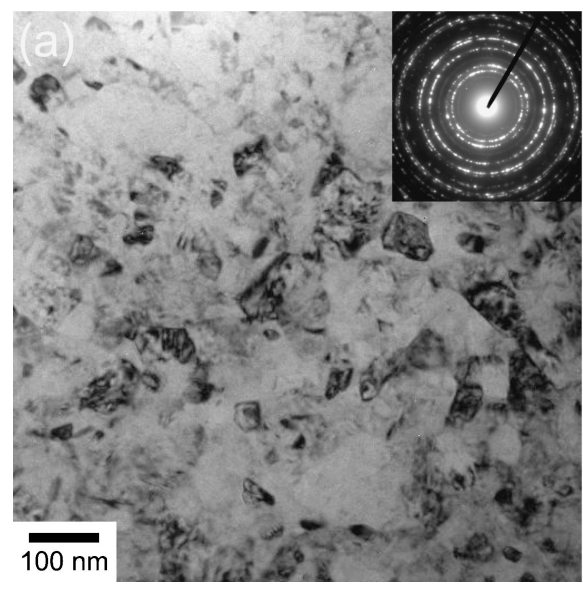

Table 3 にまとめた. 配向度 $N_{h k l}$ の算出には以下の式 $(2) を$ 用いた。

$$
N_{h k l}=\frac{I_{h k l}}{I_{111}+I_{200}+I_{220}} / \frac{I_{h k l}^{\prime}}{I_{111}^{\prime}+I_{200}^{\prime}+I_{220}^{\prime}}
$$

ここで, $I_{h k l}$ は本研究で得られた電析 $\mathrm{Ni}-\mathrm{W}$ 合金における回 折ピーク強度であり， $I_{h k l}^{\prime}$ は ICDD のデータベースから得ら れる標準ニッケルに拈ける回折ピーク強度を示す. SG6 か ら作製した試料を除くすべての試料において，(200)面への 配向が確認された。 また, SPNG 浴から得られた試料は, 従来浴の SPG 浴から得られた試料と同程度の配向度を示し た. SG 浴に拈いては，グルコン酸ナトリウムの添加量が増 加するとともに，(200)面への配向が強まる結果となった. 一方で, SG6 浴から作製した試料は，(220)面に非常に強く 配向していた．これらの配向性の変化は, 電析時のタングス テン析出量の減少，水素ガスの発生によりそれぞれ成長モ一 ドが free lateral growth mode, inhibited out-growth mode に 推移したものと考えられる. 特に, SG6 浴から得られた試 料に抢いて, 他の試料と比して炭素, 硫黄, タングステン含 有量などで異なる值が確認されたが，これは主に成長モード が他の試料と異なることが大きな要因であると考えられる. また，電析 $\mathrm{Ni}-\mathrm{W}$ 合金における配向性と成長モードの関係 については，文献 21)を参照されたい.

さらに，(111)面からの回折ピークに抢ける半值幅とシェ ラーの式を用いて粒径の概算を行った結果を Table 3 に示 す。過去の報告26) と同様に，電析 $\mathrm{Ni}-\mathrm{W}$ 合金の粒径は，夕 ングステン濃度の増加とともに減少する傾向が確認された。 実際に，タングステン量が 0.5 at\% から 3.1 at\%に増加する ことで，粒径は $27 \mathrm{~nm}$ から $11 \mathrm{~nm}$ に減少した。さらに， TEM を用いた直接微細組織観察を行った. Fig. 5 に SPNG 浴とSG13 浴から作製した電析バルクナノ結晶 $\mathrm{Ni}-\mathrm{W}$ 合金 の代表的な明視野像および回折パターンを示す。各 TEM 像 に掞いて，20〜30 nm 程度の結晶粒が多数確認できる.

TEM による微細組織観察において, 半值幅より算出した結 晶粒と同程度の結晶粒を確認することができた.

各種浴から得られた電析バルクナノ結晶 $\mathrm{Ni}-\mathrm{W}$ 合金の機 械的特性評価としてマイクロビッカース硬さ試験および引張

Fig. 5 Bright-filed TEM images of bulk nanocrystalline Ni-W alloys electrodeposited from (a) SPNG bath and (b) SG13 bath, with corresponding electron diffraction pattern. 
試験を行った。 Table 3 に硬さ試験の結果をまとめたＳG6 浴から作製した試料を除き，電析 $\mathrm{Ni}-\mathrm{W}$ 合金は， $4.7 〜 5.0$ $\mathrm{GPa}$ 程度の硬さを有して抢り，また，その硬さは非常に均 一なものであった。一方で, SG6 浴から作製した試料は, $5.2 \mathrm{GPa}$ と他の試料に比して高い硬度を示した。これは, SG6 浴から作製した試料は，他の試料に比べて高いタング ステン含有量および微細な結晶粒を有していることに起因し ている.しかしながら, 硬さ試験において圧痕付近に割れが 発生したため, その硬度にはばらつきが見られた. SG6 浴 から得られた試料において脆性的な挙動が見られたため, 以 降の実験では SG6 浴以外の浴から得られた試料に対して行 った.

ナノ結晶金属材料の強度には, 結晶粒サイズ(結晶粒微細 化効果) や溶質濃度 (固溶強化) に加えて, 粒界が平衡状態に あるかどうかが影響を与える. メカニカルアロイングや電析 により作製されたナノ結晶材料は, 過剩転位, ミスフィット 領域, または過㮃自由体積を含んだ非平衡な粒界が確認され ている.これらの材料に対して, 粒界拡散を促す低温熱処理 を施すことで, 結晶粒成長を伴わずに粒界がより平衡状態に 遷移することが報告されている27).さらに，粒界に打ける 非平衡状態から平衡状態への遷移により, 強度が向上するこ とが粒界緩和強化として報告されている18,28). それゆえ, ナ ノ結晶材料に対して低温熱処理を施し, 硬さ変化を調査する ことで，簡易的に粒界の状態を予測することが可能であると 考えられた。

そこで, 本研究で作製した各試料に対して $200^{\circ} \mathrm{C}$ の低温 熱処理を施し, 硬さの変化を調査した. 結果を Fig. 6 に示 す。従来浴である SPG 浴から作製した試料においては, 熱 処理により硬さが，4.9 GPa から $5.0 \mathrm{GPa}$ 程度と $2 \%$ 程度の 上昇が確認された。他の試料においても, 熱処理によって $1 \%$ から $4 \%$ 程度の硬さの増加が起きた. 本結果から, SG6 浴を除く開発浴から得られた $\mathrm{Ni}-\mathrm{W}$ 合金の粒界に含まれる 過㮃体積は, 従来浴から得られる Ni-W 合金と同程度であ ると考えられた. また, 過去の報告では, 粒界緩和により最 大で $25 \%$ 程度の硬さ上昇が報告されているが28), 本研究で 作製した Ni-W 合金においては硬さの向上は最大でも $4 \%$ 程
度であり, 電析ままの状態から粒界が平衡状態に近い状態に あるものと推測された.

Table 4 に引張試験の結果をまとめた. また, Fig. 7 に各 種浴から作製した電析バルクナノ結晶 $\mathrm{Ni}-\mathrm{W}$ 合金より切り 出した試験片 $\mathrm{A}$ の応力ーひずみ曲線を示す. 本研究抢いて は, 同一の試料から 2 本の引張試験片 $(\mathrm{A}, \mathrm{B})$ を切り出し (Fig. 1(a)), 引張試験を行ったが，5種類の試料すべてにお

Table 4 Tensile properties of bulk nanocrystalline $\mathrm{Ni}-\mathrm{W}$ alloys.

\begin{tabular}{ccccr}
\hline Bath & Specimens & $\sigma_{0.2} / \mathrm{GPa}$ & $\sigma_{\mathrm{UTS}} / \mathrm{GPa}$ & $\varepsilon(\%)$ \\
\hline SPG & $\mathrm{A}$ & 1.12 & 1.66 & 6.5 \\
& $\mathrm{~B}$ & 1.14 & 1.62 & 3.7 \\
SPNG & $\mathrm{A}$ & 1.07 & 1.65 & 11.3 \\
& $\mathrm{~B}$ & 1.08 & 1.66 & 7.8 \\
SG13 & $\mathrm{A}$ & 1.19 & 1.80 & 5.2 \\
& $\mathrm{~B}$ & 1.16 & 1.76 & 3.4 \\
SG19 & $\mathrm{A}$ & 1.18 & 1.72 & 5.8 \\
& $\mathrm{~B}$ & 1.15 & 1.70 & 4.6 \\
SG26 & $\mathrm{A}$ & 1.08 & 1.67 & 8.7 \\
& $\mathrm{~B}$ & 1.20 & 1.66 & 5.0 \\
\hline
\end{tabular}

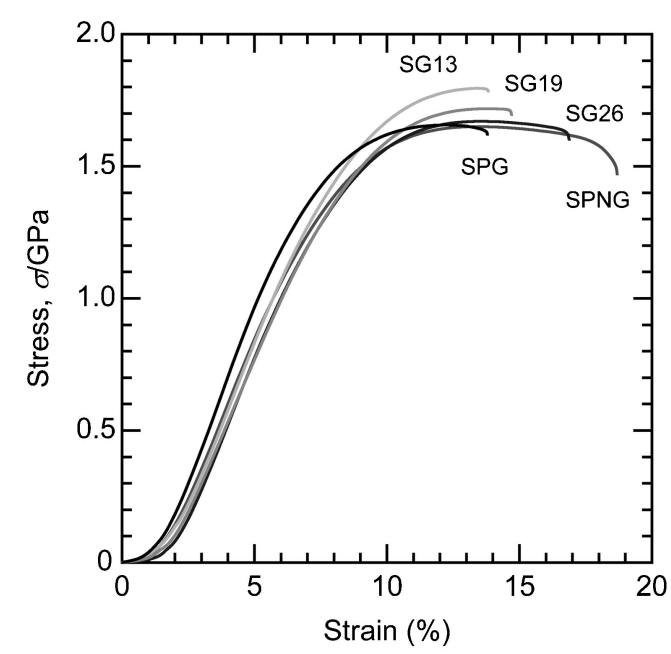

Fig. 7 Stress-strain curves of tensile specimen A obtained from the bulk nanocrystalline $\mathrm{Ni}-\mathrm{W}$ alloys electrodeposited from various deposition baths.
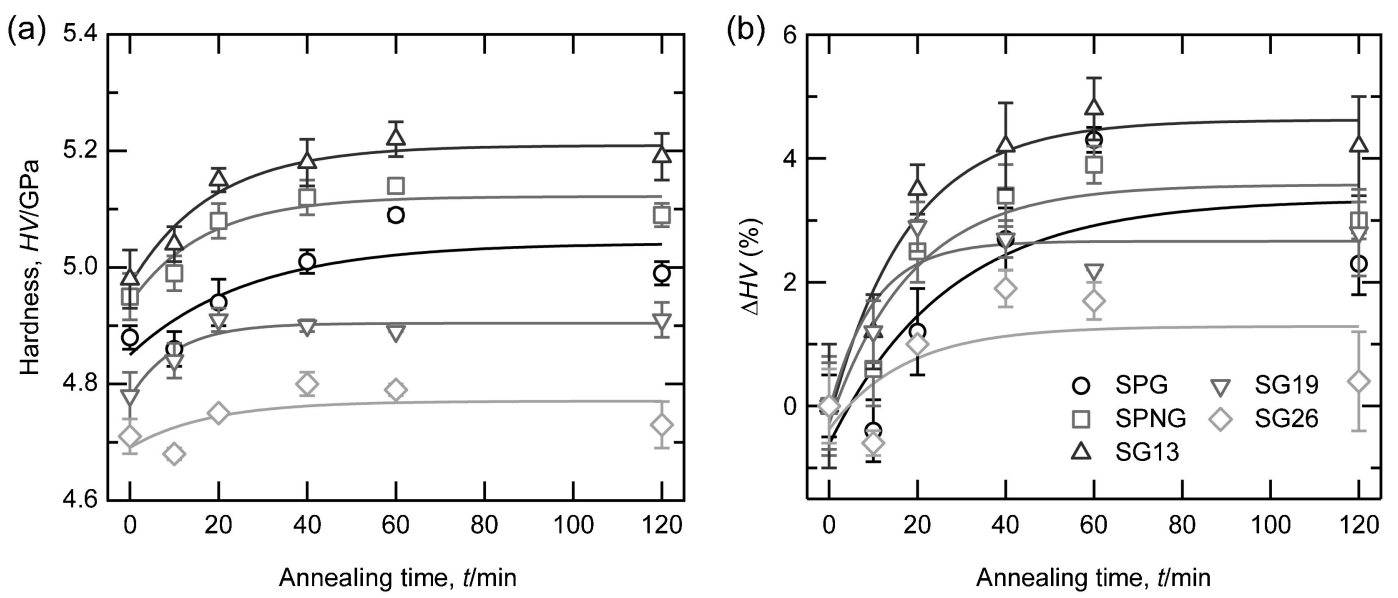

Fig. 6 (a) Hardness versus annealing time for electrodeposited bulk nanocrystalline Ni-W alloys for annealing temperatures at $200^{\circ} \mathrm{C}$. (b) Change in hardness for bulk nanocrystalline Ni-W alloys as a function of annealing time. 
いて試験片 $\mathrm{A}$ が試験片 B に対して優れた延性を示した。こ れらの原因として, 本研究における電析では, 浴中のニッケ ル，タングステン濃度を一定に保つために可溶性陽極として ニッケル極とタングステン極を用い，2つの陽極にそれぞれ に電流を $0.367 \mathrm{~A}, 0.008 \mathrm{~A}$ と不均一に印加していることが 挙げられる. 実際に，Fig. 2 に示す各試料の外観写真におい ても左側 (ニッケル極側)のエッジ部と右側 (タングステン極 側)のエッジ部を比較するとニッケル極側の方がより厚く電 析されていることが確認できる，基板の左右において電流密 度の強弱が括き, 結果として延性に影響を与えたものと考え られる，今後は，電流密度の分布が均一になるように陽極の 配置を改善していく次第である。 また，本試験においては， 印加電流の小さいタングステン極に近接した部位から加工を 行った試験片 B が低い延性を示した.

以降では，優れた延性を示した試験片 $\mathrm{A}$ の結果に基づい て，電析バルクナノ結晶 $\mathrm{Ni}-\mathrm{W}$ 合金の引張特性について議 論を行っていく，従来浴の SPG 浴から得られた試料は，引 張強度 $1.66 \mathrm{GPa}$ ，破断伸び $6.5 \%$ を示した。 これに対して， SG13 浴抢よび SG19 浴から得られた電析 Ni-W 合金は，そ れぞれ引張強度 $1.80 ， 1.72 \mathrm{GPa}$ を示しており引張強度の向 上が確認された。 また, SPNG 浴から得られた電析 $\mathrm{Ni}-\mathrm{W}$ 合金に拈いては, 従来浴と同程度の引張強度を有しながら, 11.3\%という優れた引張伸びを示した．Fig. 8 に引張試験後 の平行部の外観ならびに破断面の SEM 像を示す。特に, SPNG 浴から得られた試料において，明瞭なネッキングが 生じていた (Fig. 8(b)). また，各引張試験片の破断面に延 性破壊時に見られるディンプルパターンが形成していた

(Fig. 8(f) $\sim(\mathrm{j}))$.

本研究において, SPG 浴から得られたバルクナノ結晶 $\mathrm{Ni}-\mathrm{W}$ 合金の引張特性は, 過去に報告 ${ }^{20}$ )した引張特性 (引張 強度 $1.5 \mathrm{GPa}$ ，引張伸び $13 \%$ ) に比べて，引張強度が高く， 引張伸びが低かった。この要因としては，過去の研究で使用 した $5 \mathrm{~L}$ 電析浴槽と本研究で使用した $1 \mathrm{~L}$ 電析浴槽におい て，攪挥速度が同一でないことが挙げられる．今後は，電析 システムに流量計を組み込み，浴流の定量化ならびにその影 響の調査を行っていく予定である.

一連の研究結果から, プロピオン酸の代替物質としてプロ ピオン酸ナトリウムを用いた電析浴から作製したバルクナノ 結晶 $\mathrm{Ni}-\mathrm{W}$ 合金は，従来浴から得られた Ni-W 合金と同程 度のタングステン濃度，不純物量，配向性，結晶粒径，抢よ び引張強度に加えて，引張伸びの向上が確認された。一方 で，グルコン酸ナトリウムのみを錯化剂として用いた電析浴 から作製したバルクナノ結晶 $\mathrm{Ni}-\mathrm{W}$ 合金は，グルコン酸ナ トリウム添加量の増加に伴ってタングステン含有量が減少し 結晶粒サイズが増加する傾向が確認された。それにもかかわ らず，引張試験においては，従来浴から得られた電析合金よ りも高い引張強度を示した．電析バルクナノ結晶 $\mathrm{Ni}$ 合金の 強度を及ぼす因子として，電析プロセスに由来した侵入型炭 素による固溶強化 ${ }^{16)}$ や粒界緩和強化 ${ }^{18)}$ などが挙げられるが, SG6 浴を除く SG 浴から得られた Ni-W 合金の炭素濃度は, 0.03 at\% と低い值であり強度への影響は無視でき，また， 前述のと扣り粒界緩和強化についてもその影響は小さい. 現
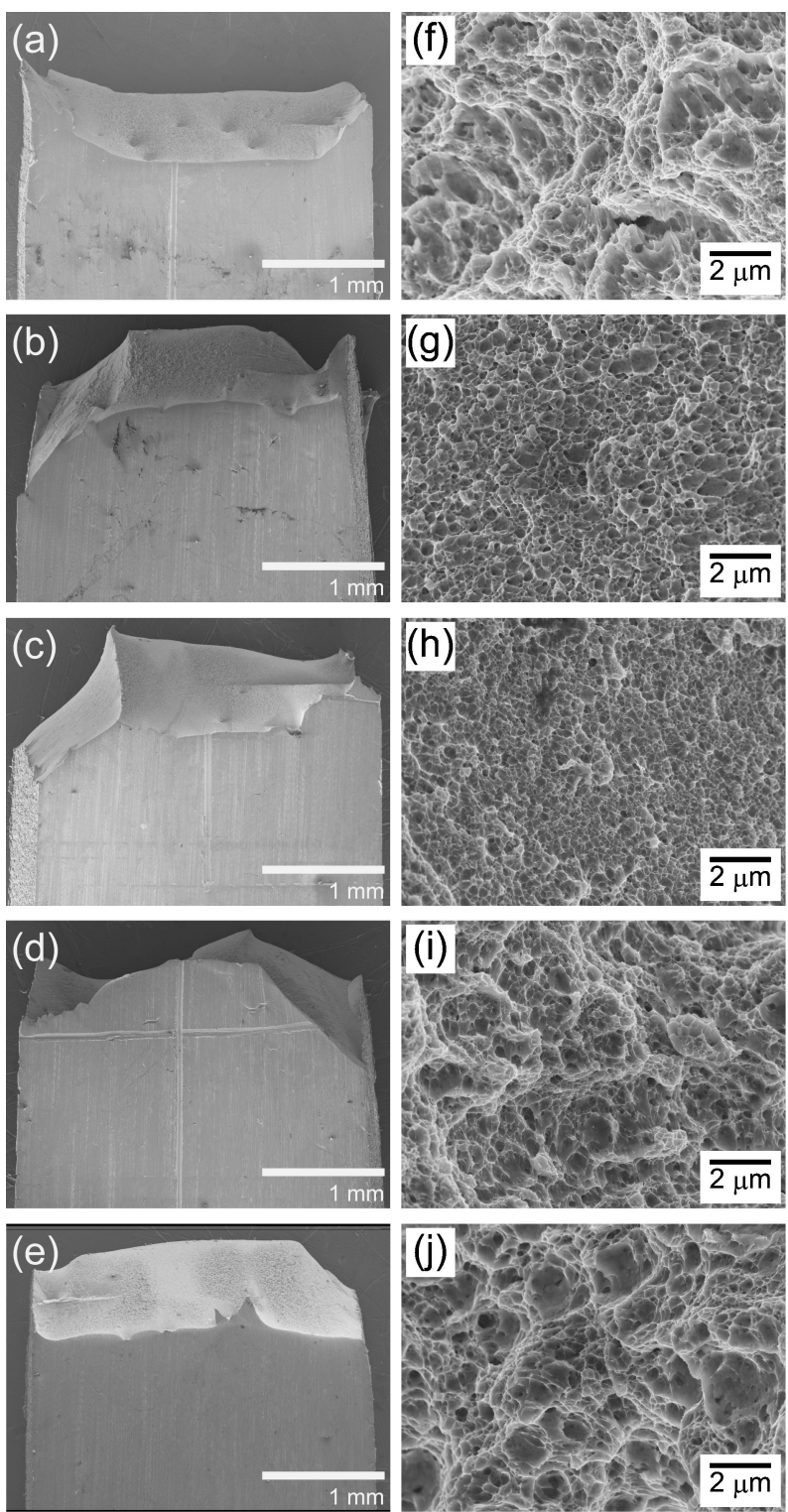

Fig. 8 SEM images showing gauge section (a)-(e) after a tensile test and fracture surfaces (f) - (j) of tensile specimen A obtained from the bulk nanocrystalline electrodeposited $\mathrm{Ni}-\mathrm{W}$ alloys. (a) (f) SPG, (b) (g) SPNG, (c) (h) SG13, (d) (i) SG19, (e) (j) SG26.

在，この点については，グルコン酸ナトリウムのみを添加し た SG 浴とプロピオン酸もしくはプロピオン酸ナトリウムを 添加したSPG 浴, SPNG 浴で，電析皮膜の成長形態が異な っていること(Fig. 2) が関与しているのではないかと考えて いる. 今後, これらの影響について明らかにしていく必要が ある。

\section{4. 結 言}

錯化剂の異なる 6 種類の $\mathrm{Ni}-\mathrm{W}$ 電析浴を用いてバルクナ ノ結晶 $\mathrm{Ni}-\mathrm{W}$ 合金の作製抢よびその機械的特性評価を行 い，プロピオン酸の代替について検討を行った. プロピオン 酸ナトリウムを添加した SPNG 浴は，従来浴である SPG 浴 と同等の電流効率を示すとともに，タングステン濃度，粒 
径, 配向性, および硬度において同程度のバルクナノ結晶 $\mathrm{Ni}-\mathrm{W}$ 合金の作製が可能であった。 さらに，SPNG 浴から得 られた電析バルクナノ結晶 $\mathrm{Ni}-\mathrm{W}$ 合金は, 引張強度 1.65 $\mathrm{GPa}$, 引張伸び $11.3 \%$ という優れた引張特性を示し, 従来 浴から得られた電析合金に対して引張伸びの改善が確認され た.プロピオン酸の添加をせず $\mathrm{Ni}-\mathrm{W}$ 電析浴の錯化剂をグ ルコン酸ナトリウムのみにした SG 浴では, 添加量を 12.8 $\mathrm{g} / \mathrm{L}$ 以上にすることでバルクナノ結晶 $\mathrm{Ni}-\mathrm{W}$ 合金の作製が 可能になった. 従来浴に比して, 得られる電析合金のタング ステン含有量が減少し粒径が増加しているにもかかわらず, 引張強度が向上した. 本引張強度増加については, 電析時に おける成長形態の違いによる可能性が考えられた。本研究に より, 従来の SPG 浴は, プロピオン酸ナトリウムを用いた SPNG 浴で代替可能であることが明らかになり，これによ り高強度・高延性バルクナノ結晶 $\mathrm{Ni}-\mathrm{W}$ 合金電析浴に打け る規制対象試薬のフリー化を実現した，同時に，延性よりも 強度が必要となる場合に打いては錯化剤としてグルコン酸ナ トリウムのみを用いた SG 浴, 特に SG13 浴が有効であるこ とが示された。

本研究は, JSPS 研究活動スタート支援 (課題番号： 26886014)の助成によって実施された.

\section{文献}

1) M. A. Meyers, A. Mishra and D. J. Benson: Prog. Mater. Sci. 51 (2006) 427-556.

2) M. Dao, L. Lu, R. Asaro, J. Dehosson and E. Ma: Acta Mater. 55 (2007) 4041-4065.

3) T. Yamasaki, P. Schlossmacher, K. Ehrlich and Y. Ogino: Nanostruct. Mater. 10 (1998) 375-388.

4) T. Yamasaki: Scr. Mater. 44(2001) 1497-1502.

5) C. A. Schuh, T. G. Nieh and T. Yamasaki: Scr. Mater. 46 (2002) 735-740.
6) K. Fujita, T. Suidu and T. Yamasaki: J. Japan Inst. Metals $\mathbf{7 5}$ (2011) 348-354.

7) S. Nakayama, H. Adachi and T. Yamasaki: J. Alloy. Compd. 643 Supplement 1 (2015) S22-S26.

8) U. Erb, K. T. Aust and G. Palumbo: Electrodeposited Nanocrystalline Metals, Alloys, and Composites, in Nanostructured Materials: Processing, Properties, and Applications, ed. by C. C. Koch, (William Andrew, Inc., Norwich, N.Y., 2007) pp. 235-292.

9) I. Brooks, G. Palumbo, G. D. Hibbard, Z. R. Wang and U. Erb: J. Mater. Sci. 46(2011) 7713-7724.

10) I. Matsui, S. Ono, Y. Takigawa, T. Uesugi and K. Higashi: Mater. Sci. Eng. A 550(2012) 363-366.

11) I. Matsui, Y. Takigawa, T. Uesugi and K. Higashi: Mater. Lett. 99 (2013) 65-67.

12) A. M. El-sherik and U. Erb: J. Mater. Sci. 30 (1995) 5743-5749.

13) C. Cheung, F. Djuanda, U. Erb and G. Palumbo: Nanostruct. Mater. 5(1995) 513-523.

14) Y. Zhou, U. Erb, K. T. Aust and G. Palumbo: Scr. Mater. 48 (2003) 825-830.

15) D. Wu, J. Zhang, J. C. Huang, H. Bei and T. G. Nieh: Scr. Mater. 68(2013) 118-121.

16) I. Matsui, T. Uesugi, Y. Takigawa and K. Higashi: Acta Mater. 61 (2013) 3360-3369.

17) C. A. Schuh, T. G. Nieh and H. Iwasaki: Acta Mater. 51(2003) 431-443.

18) I. Matsui, H. Mori, T. Kawakatsu, Y. Takigawa, T. Uesugi and K. Higashi: Mater. Sci. Eng. A 607 (2014) 505-510.

19) I. Matsui, T. Kawakatsu, Y. Takigawa, T. Uesugi and K. Higashi: Mater. Lett. 116(2014) 71-74.

20) I. Matsui, Y. Takigawa, T. Uesugi and K. Higashi: Mater. Sci. Eng. A 578(2013) 318-322.

21) I. Matsui, Y. Takigawa, D. Yokoe, T. Kato, T. Uesugi and K. Higashi: Mater. Trans. 55(2014) 1859-1866.

22) M. Watanabe, Y. Wakuda, Y. Nakamaru, K. Tashiro and H. Honma: J. Surf. Finish. Soc. Jpn. 58(2007) 317-324.

23) Y. Nakamaru, Y. Wakuda, K. Tashiro, M. Watanabe and H. Honma: J. Surf. Finish. Soc. Jpn. 59(2008) 133-137.

24) Y. Wakuda, K. Yoshida, K. Tashiro and H. Honma: J. Surf. Finish. Soc. Jpn. 62(2011) 131-137.

25) I. Kato, Y. Wakuda, K. Tashiro, Y. Umeda and H. Honma: J. Surf. Finish. Soc. Jpn. 63(2012) 41-46.

26) Y. Takigawa, S. Wakayama, I. Matsui, T. Uesugi and K. Higashi: Mater. Trans. 52(2011) 37-40.

27) D. Jang and M. Atzmon: J. Appl. Phys. 99(2006) 083504.

28) T. J. Rupert, J. R. Trelewicz and C. A. Schuh: J. Mater. Res. 27 (2012) 1285-1294. 